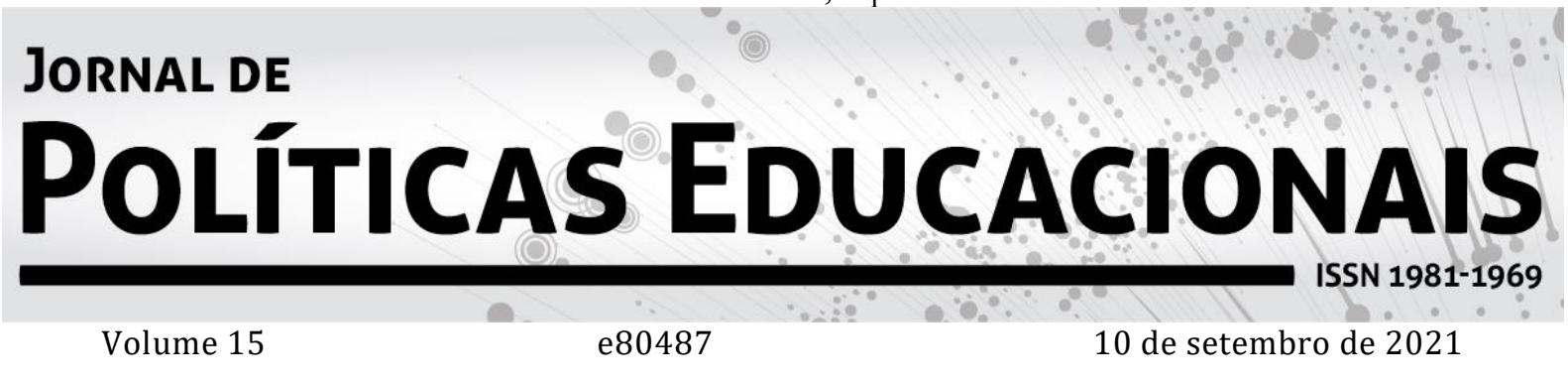

\title{
As lutas dos professores paranaenses entre os anos de 1988 e 2015 por condições de trabalho: conflitos e consensos, repressões e resistências $^{1}$
}

\section{The fights of Paraná teachers from 1988 and 2015 for working conditions: conflicts and consensus, repression and resistance}

\section{Las luchas de los docentes de Paraná (1988 y 2015) por condiciones de trabajo: conflictos y consensos, represión y resistencia}

Citação: SOUZA, R. D. de. As lutas dos professores paranaenses entre os anos de 1988 e 2015 por condições de trabalho: conflitos e consensos, repressões e resistências. Jornal de Políticas Educacionais. e80487. Setembro de 2021

\section{http://10.5380/jpe.v15i0.80487}

Resumo: Este artigo tem por objetivo contextualizar histórica e politicamente as lutas dos professores do Paraná, entre os anos de 1988 e 2015, por condições de trabalho. Os dados são oriundos da pesquisa documental e em registros fotográficos de jornais, foram analisados qualitativamente a partir do método do Materialismo Histórico e Dialético. As principais categorias de estudo e análise foram: Historicidade, Ideologia, Estado, Luta de Classes, Conflitos e Consensos, Repressões e Resistências docentes. Constatou-se que, nas fotografias e conteúdos jornalístico que remetem a 27 anos de lutas docentes, as contradições que permeiam a realidade são construídas historicamente e cumprem a função de naturalizar e formar um consenso na população, que mascara a irresponsabilidade do Estado e culpabiliza os professores nas lutas políticas por melhores condições de trabalho.

Palavras-chave: Políticas Públicas em Educação. Valorização do Professor. Trabalho e Educação.

Abstract: The purpose of this article is to contextualize the struggles, by working conditions, of teachers from Paraná between the years 1988 end 2015. The data from documentary research and in photographic

\footnotetext{
${ }^{1}$ Pesquisa financiada pela Coordenação de Aperfeiçoamento de Pessoal de Nível Superior - Brasil (CAPES) - Código de Financiamento 001.

2 Doutor em Educação Científica e Tecnológica (UFSC). Professor Pesquisador da Faculdade de Educação da Universidade de Brasília (FE/UnB), atua na Graduação e na Pós-Graduação em Educação (PPGEMP) e na Pós-Graduação em Educação em Ciências (PPGEduC). Orcid: http://orcid.org/0000-0002-4157-6116. Email: professor.rodrigosouza@gmail.com
} 


\section{JORNAL DE \\ Políticas EduCACIONAIS \\ ISSN 1981-1969}

records of newspapers and were analyzed qualitatively using the method of Historical and Dialectical Materialism. The main categories of study and analysis were: Historicity, Ideology, State, Class Struggle, Conflicts and Consensus, Repressions and Teachers' Resistances. It was found, in the photographs that refer to 27 years of teaching struggles, that the contradictions that permeate reality are historically constructed and fulfill the function of naturalizing and forming a consensus in the population that masks the irresponsibility of the State and blames teachers in the struggles for better working conditions.

Keywords: Public Policies in Education. Teacher Appreciation. Work and Education.

Resumen: Este artículo tiene como objetivo contextualizar histórica y políticamente las luchas de los docentes de Paraná, entre 1988 y 2015, por las condiciones de trabajo. Los datos provienen de investigaciones documentales y de registros fotográficos de periódicos, y se analizaron cualitativamente utilizando el método del materialismo histórico y dialéctico. Las principales categorías de estudio y análisis fueron: historicidad, ideología, estado, lucha de clases, conflictos y consensos, represiones y resistencias docentes. En las fotografias y en contenido periodístico que se refieren a 27 años de luchas docentes, las contradicciones que impregnan la realidad se construyen históricamente y cumplen la función de naturalizar y formar un consenso en la población, que oculta la irresponsabilidad del Estado y culpa a los maestros en las luchas por una mejor condiciones de trabajo.

Palabras-clave: Políticas Públicas en Educación. Apreciación Docente. Trabajo y Educación.

\section{Introdução}

Prestar atenção no presente, se se quer transformá-lo. Pessimismo da inteligência, otimismo da vontade.

Cadernos do Cárcere, Antonio Gramsci.

As palavras de Gramsci ecoam à luta da classe trabalhadora para viver e sobreviver. Luta que exige olhar a realidade em suas contradições e, a partir dela, ser possível um otimismo da vontade para lutar por uma nova sociedade.

Nessa direção, a problemática desta pesquisa indaga: Como se dão as lutas dos docentes do Paraná por condições de trabalho? Na busca de respostas, objetivou-se contextualizar histórica e politicamente as lutas dos professores do Paraná nos anos de 1988 e 2015, com a hipótese de que as contradições que permeiam as lutas e a desvalorização do trabalho docente são operadas pelo estado, por meio das ações políticas dos governos, construídas historicamente, fortalecidas pela ideologia dominante, que constroem um consenso na população, alinhando-se à culpabilização docente.

0 referencial que fundamenta a pesquisa teórica e metodologicamente ${ }^{3}$ é 0 Materialismo Histórico e Dialético, especialmente nas obras de Engels (2010); Lênin

\footnotetext{
${ }^{3} \mathrm{O}$ desenvolvimento da pesquisa foi aprovado via parecer consubstanciado $\mathrm{n}^{\circ} 2.165 .105$ no Comitê de Ética em Pesquisa com Seres Humanos (CEPSH-UnB).
} 
SOUZA, R. D. de. As lutas dos professores paranaenses entre os anos de 1988 e 2015 por condições de trabalho: conflitos e consensos, repressões e resistências

\section{JORNAL DE \\ Políticas EducacionaIS \\ ISSN 1981-1969}

(1982); Marx \& Engels (2005); Marx \& Engels (2007); Marx (2011). Nessa perspectiva a relação entre a teoria e a realidade não estão dualizadas, mas, ao mesmo tempo em que se discutem os dados se realiza o movimento dialético com o referencial teórico, analisando-se o objeto em questão a partir das categorias do método e das categorias que emergem dos dados. As principais categorias nesta pesquisa são: a Historicidade, a Ideologia, o Estado, a Luta de Classes, os Conflitos e Consensos, as Repressões e as Resistências docentes.

Assim, neste artigo, inicialmente, contextualiza-se o objeto de estudo, depois, apresenta-se brevemente a distribuição numérica dos professores no Paraná e aspectos das condições objetivas e Políticas de Valorização e Remuneração. Por último, expõem-se as lutas e resistências dos docentes a partir de registros fotográficos e jornalísticos. Durante todo o artigo é realizada a exposição dos dados e a discussão dos mesmos dialeticamente com a fundamentação teórica a partir do Materialismo Histórico e Dialético.

\section{Os Professores do Paraná}

O estado do Paraná, situado na Região Sul do Brasil, ocupa uma área de 199.880 $\mathrm{km}^{2}$. Segundo indicadores selecionados pelo IPARDES - Instituto Paranaense de Desenvolvimento Econômico e Social (IPARDES, 2017), o estado tem uma taxa de alfabetização de adultos em 93,72\% (IBGE, 2010), o IDH-M - Índice de Desenvolvimento Humano Municipal em 0,749 (PNUD; IPEA; FJP, 2010), a expectativa de vida ao nascer em 74,80 anos (PNUD; IPEA; FJP, 2010) e a densidade demográfica de 52,25 hab/ $\mathrm{km}^{2}$ (IPARDES, 2016). Os recortes regionais do território paranaense são apresentados em Mesorregiões (Fig. 1) e Microrregiões, segundo o IBGE, e em Regiões Geográficas, conforme a Lei Estadual no 15.825/08 - Paraná.

Considerar a distribuição das mesorregiões do estado do Paraná permite o entendimento de que o desenvolvimento regional é marcado pela modernização da base produtiva concentrada em alguns polos, que revelam a desigualdade social no interior das 


\section{JORNAL DE \\ Políticas Educacionals \\ ISSN 1981-1969}

mesorregiões (IPARDES; BRDE, 2004, p. 3). Associado a isso, acentua-se a disparidade da distribuição da população com o aumento ou a baixa densidade demográfica no interior das mesorregiões, assim como entre elas. Ou seja, a população por meio do êxodo rural e/ou urbano passa a se concentrar em algumas regiões na busca da inserção ao mercado de trabalho formal e/ou informal (IPARDES; BRDE, 2004, p. 3).

Figura 1: Mapa das Mesorregiões do Estado do Paraná - IBGE (2010).

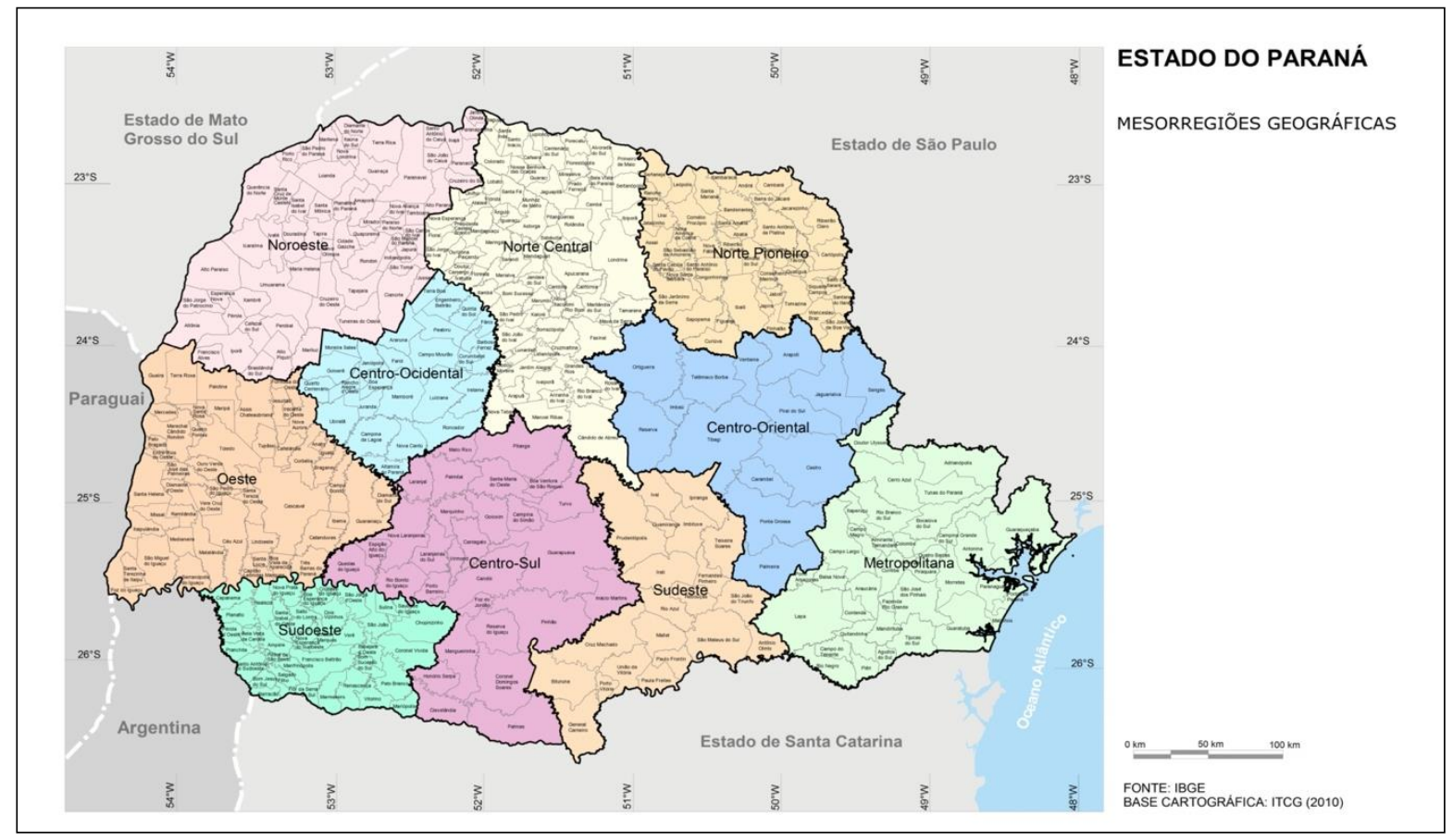

Fonte: IBGE (2010).

Desse modo, a modernização da base produtiva é intensificada com a expansão do agronegócio, acarretando o aumento no uso de agrotóxicos, a minimização da agricultura familiar, a urbanização em larga escala sem um planejamento para saneamento básico e saúde pública (IPARDES; BRDE, 2004, p. 3).

A extensão territorial do estado e sua própria história são marcadas por diferentes movimentos de colonização, exploração e povoamento, perpassando pela organização dos movimentos sociais, da Teologia da Libertação, pela presença de tropeiros, imigração de europeus como colonos para produção de alimentos para subsistência e pela migração de produtores rurais paulistas e mineiros (STECA; FLORES, 2008). Além disso, há a 


\section{JORNAL DE \\ POLÍTICAS EDUCACIONAIS \\ ISSN 1981-1969}

manutenção e a permanência das identidades regionais e culturais do Paraná (IBGE, 1990, p. 8).

Entende-se que, na conjuntura capitalista, a relação entre o capital, o trabalho e a educação estão intimamente ligadas ao modelo de governança dos gestores do estado. Esses estão alinhados aos valores da sociedade neoliberal que defendem a educação como base do desenvolvimento ou fracasso econômico, sendo o docente um dos principais protagonistas ou o culpado. Assim, a distribuição quantitativa dos professores no território paranaense também está associada com o desenvolvimento regional.

Compreende-se que desde a distribuição dos docentes no território à gestão da Educação Pública, não é isenta de valores e ideologias do grupo político e das ações políticas que gestam a Educação Básica e o desenvolvimento regional por meio da educação.

Pontua-se, então, que a organização da Educação Básica nos 399 municípios paranaenses, via Secretaria de Estado da Educação (SEED-PR), está estruturada em 32 Núcleos Regionais de Educação. Optou-se por identificar o número total de professores que atuam na Rede Estadual do PR via canal online ${ }^{4}$ de acesso das informações públicas.

Na Tabela 1, apresentam-se os dados referentes ao número e ao vínculo dos docentes ao Estado nos anos de 2012 a 2017, tendo o ano de 2017 como referência de consulta e análise comparativa.

Tabela 1: Total de Professores da SEED PR conforme Mês/Ano de Referência - 2012 a 2017.

\begin{tabular}{l|l|l|l|l|l|l|l}
\hline Mês/Ano & Total de & Vínculos & \multicolumn{4}{l}{} \\
\cline { 3 - 8 } de Referência & Pessoas & QPM-P & QPM-E & QUP & PEPR & PEPE & REPR \\
\hline julho/2017 & 69.929 & 43.470 & 6.053 & 25 & 1 & 1 & 20.379 \\
\hline julho /2016 & 77.346 & 44.860 & 6.220 & 27 & 1 & 1 & 26.237 \\
\hline julho /2015 & 73.545 & 46.303 & 6.387 & 29 & 1 & 1 & 20.824 \\
\hline julho /2014 & 77.437 & 44.240 & 5.744 & 35 & 1 & 1 & 27.416 \\
\hline julho /2013 & 76.669 & 44.940 & 5.845 & 41 & 1 & 1 & 25.841 \\
\hline julho /2012 & 74.113 & 46.048 & 6.030 & 44 & 1 & 1 & 21.989 \\
\hline & & & & & & & \\
\hline Total do Estado & 449.039 & 269.861 & 36.279 & 201 & 6 & 6 & 142.686 \\
\hline
\end{tabular}

Fonte: SAE - Sistema de Administração Escolar da SEED-PR, elaborado pelos autores.

${ }^{4}$ http://www4.pr.gov.br/escolas/numeros/index.jsp. 


\section{JORNAL DE Políticas EducacionaIS

Legenda: Professores do Quadro Próprio Magistério (QPM-P); Especialistas do Quadro Próprio Magistério (QPM-E); Professores do Quadro Único de Pessoal (QUP); Professores Contratados pelo Paraná Educação (PEPR); Paraná Educação - Pedagogos (PEPE); Regime Especial - Professor (REPR).

Em julho de 2017 há um total de 69.929 docentes no Paraná, o que nos permite visualizar o número expressivo de docentes com vínculo à SEED-PR. Aproximadamente 60\% dos professores são QPM-P e 31,7\% do Regime Especial - Professor (REPR). Verificase que julho de 2017 é o mês que possui o menor número de docentes empregados. Esses dados despertaram para a verificação estatística do percentual de diferença de contratações, entre os meses de referência, nos anos de 2012 a 2016 com o ano de 2017, conforme está na Tabela 2:

Tabela 21: A diferença do número total de Professores/Pessoas/Vínculos da SEED PR no mês de julho de 2017 em comparação com o mesmo mês nos anos de 2012 a 2016.

\begin{tabular}{l|l|l|l}
\hline Mês/Ano & Total & Julho/2017 & Diferença \\
\hline julho/2016 & 77.346 & 69.929 & $7.417(9,58 \%)$ \\
\hline julho/2015 & 73.545 & 69.929 & $3.616(4,91 \%)$ \\
\hline julho/2014 & 77.437 & 69.929 & $7.508(9,69 \%)$ \\
\hline julho/2013 & 76.669 & 69.929 & $6.740(8,79 \%)$ \\
\hline julho/2012 & 74.113 & 69.929 & $4.184(5,64 \%)$ \\
\hline
\end{tabular}

Fonte: SAE - Sistema de Administração Escolar da SEED-PR, elaborado pelos autores.

Em todos os anos analisados, está presente um diferencial significativo de contratações, num comparativo com 2017 e especialmente com 2016, por exemplo, temse um diferencial de 9,58\%, que se refere a 7.417 professores não contratados pelo governo do Paraná, o que sugere, por consequência, um aumento de desemprego docente, sendo o Estado um dos principais empregadores de professores.

Referente a isso, a diminuição das contratações não consiste apenas no desemprego, mas também na precarização e intensificação do trabalho que pioram as condições de trabalho, como apontou o prof. João5 ${ }^{5}$ em entrevista em julho de 2017:

\footnotetext{
${ }^{5}$ Nome fictício atribuído ao Professor da Rede Pública Estadual de Educação do Paraná que foi entrevistado nesta pesquisa. Considerando o direito ao anonimato e o termo de consentimento livre e esclarecido assinado pelo participante foi utilizado aqui o nome fictício.
} 


\section{JORNAL DE POLÍTICAS EDUCACIONAIS

[...] se fosse uma diminuição de contratação com a efetivação de uma jornada de 40h, com as horas atividades garantidas, com a contratação de concursado [...] carreira funcionando de fato, aumento de hora atividade, porque sempre defendemos um aumento da hora atividade. [...]. O governo só reduziu [a hora atividade] com o argumento de que os [professores] QPM vão ter que dar mais aulas. [...] $O$ argumento publicitário é indecente, que os professores com mais aulas (em sala) seriam melhores, e de que por eliminar PSS [professores temporários] e mais tempo para os QPM, significa melhores professores dando as aulas. Mas, se esquece de que a Lei do Piso define 1/3.

A precarização das condições de trabalho e a intensificação também piora a qualidade de vida e saúde dos trabalhadores, o que aponta para o distanciamento da efetivação de políticas públicas que visam à valorização do magistério. Isso está na fala do prof. João sobre o não cumprimento da Lei do Piso Salarial Profissional Nacional (PSPN) e, por conseguinte, de metas do Plano Nacional de Educação (PNE). Na pesquisa de Masson (2016), há indicadores de que no Paraná há o cumprimento da lei do PSPN no Piso Salarial e Hora Atividade, mas a partir da fala do professor entrevistado e dos dados numéricos de contratações apresentados, observa-se o descompasso da efetivação dessa política ao longo dos anos.

Ao indicarmos o distanciamento entre os documentos oficiais prescritos e a efetivação das Políticas Educacionais, faz-se necessário frisar avanços obtidos na formulação das políticas, nos governos do Partido dos Trabalhadores (PT), destacam-se iniciativas, como as leis: a Lei no 11.738, de 20086; a Lei no 12.014, de 20097; a Lei no 13.005, de $2014^{8}$ e o Decreto no 8.752 , de $2016^{9}$.

Atrelado a isso, as pesquisas (GROCHOSKA, 2015; MORETTI; MASSON, 2015; MASSON, 2016), sobre a condição da valorização e precarização dos professores no

\footnotetext{
${ }^{6}$ Disponível em: http://www.planalto.gov.br/ccivil 03/ato2007-2010/2008/lei/l11738.htm. Acesso em: 19 ago. 2017.

${ }^{7}$ Disponível em: http://www.planalto.gov.br/ccivil 03/ato2007-2010/2009/lei/l12014.htm. Acesso em: 19 ago. 2017.

${ }^{8}$ Disponível em: http://www.planalto.gov.br/CCIVIL 03/Ato2011-2014/2014/Lei/L13005.htm Acesso em 19 ago. 2017.

${ }^{9}$ Disponível em: http://www.planalto.gov.br/ccivil 03/Ato2015-2018/2016/Decreto/D8752.htm\#art19 Acesso em 19 ago. 2017.
} 


\section{JORNAL DE Políticas EducacionaIS

Paraná e nos demais estados brasileiros, salientam a relação de mercantilização e o distanciamento das políticas e sua real efetivação.

O estudo de Masson (2016) apresenta um cenário nacional da valorização dos professores que trabalham nas redes estaduais do Brasil, analisa o vencimento inicial, a jornada de trabalho, o cumprimento do PSPN e as leis que regulamentam os planos de carreira dos professores dos estados brasileiros, e aponta:

Os dados indicam que das 27 (vinte e sete) unidades federativas, 16 (dezesseis) cumpriam integralmente, em 2014, a Lei do Piso no 11.738 , aprovada em 2008, representando somente 59\% do total. Em relação ao estado que apresenta o melhor vencimento inicial (Mato Grosso do Sul) e o que possui o pior vencimento (Amapá), a diferença é de quase três vezes, ou seja, o menor vencimento corresponde a 34\% do maior. (MASSON, 2016, p. 165).

Outro estudo importante de Moretti e Masson (2015), analisou a efetivação de planos de carreira e o pagamento do Piso Salarial Profissional Nacional e suas implicações na valorização dos professores da rede municipal dos cinco municípios de maior IDHM2013 e dos cinco de menor IDHM-2013 do Paraná. Elas constataram que os cinco municípios com maior IDHM-2013 do Paraná cumprem a lei do PSPN. Entre os cinco municípios com menor IDHM-2013, apenas três deles (Guaraqueçaba, Laranjal e Cerro Azul) não estavam cumprindo (MORETTI; MASSON, 2015, p. 118).

Os resultados de Moretti \& Masson (2015) e Masson (2016) enfatizam a necessidade de considerar a intensificação, as condições e a sobrecarga de trabalho dos professores vinculados às políticas salariais, como também Grochoska (2015, p. 8) ao conceituar a valorização do professor como:

Valorização do professor trata-se de um princípio constitucional que se efetiva por meio de um mecanismo legal chamado carreira, que se desenvolve por meio de três elementos, sendo: a) Formação, b) Condições de trabalho, e c) Remuneração, tendo como objetivos a qualidade da educação e a qualidade de vida do trabalhador. 
SOUZA, R. D. de. As lutas dos professores paranaenses entre os anos de 1988 e 2015 por condições de trabalho: conflitos e consensos, repressões e resistências

\section{JORNAL DE \\ Políticas EducacionaIS \\ ISSN 1981-1969}

Nesse sentido, ao considerar o depoimento do prof. João já apresentado, relacionado aos dados apresentados pelas pesquisas (GROCHOSKA, 2015; MORETTI; MASSON, 2015; MASSON, 2016) e à análise comparativa do total de docentes com vínculos com a SEED-PR, entende-se a complexidade de fatores que atentam ao trabalho e à vida destes trabalhadores, muitas vezes condicionadas ao trabalho intensificado e excessivo associado ao salário baixo que leva os professores a viverem com uma renda baixa ou buscarem renda extra com subempregos.

Relativo a isso, uma das formas de luta pela garantia de direitos são os movimentos de paralisação e greves. 0 Paraná é um dos estados com maior visibilidade quando se trata dos movimentos de luta docente por condições de trabalho, ressaltando o Massacre do 30 de agosto de 1988 e do 29 de abril de 2015.

Por isso, com o objetivo de contextualizar histórica e politicamente as lutas dos professores do Paraná entre os anos de 1988 e 2015 por condições de trabalho, além da contextualização e da discussão com as pesquisas já apresentadas, também fazemos uma incursão histórica e política nas imagens construídas socialmente sobre as lutas docentes.

\section{Vozes dissonantes sobre a realidade}

Os homens fazem a sua própria história; contudo, não a fazem de livre e espontânea vontade, pois não são eles quem escolhem as circunstâncias sob as quais ela é feita, mas estas lhes foram transmitidas assim como se encontram. A tradição de todas as gerações passadas é como um pesadelo que comprime o cérebro dos vivos.

O 18 de Brumário de Luís Bonaparte, Karl Marx.

Para transformar a realidade e a história é necessário conhecê-las, assim, denominam-se vozes dissonantes as imagens que retratam os conflitos e as lutas docentes, construídas histórica e socialmente, como imagens que refletem diferentes realidades, imagens constituídas hegemônica e ideologicamente, que são potencializadas com os meios de comunicação.

Essas imagens, no tocante aos professores do Paraná e à sua atividade profissional, contribuem para que possamos conhecer as lutas históricas desses sujeitos e desvelar 


\section{JORNAL DE Políticas EducacionaIS

discursos, práticas e tentativas de consenso por meio da manipulação da própria realidade sobre as contradições e relações de trabalho. A manipulação da realidade para os interesses do Estado, dá-se a partir da ideologia burguesa para a produção e reprodução de uma sociedade e de uma visão equivocada do real, ou seja, o real que o Estado quer que as pessoas acreditem como real, como afirma Lênin (1982, p. 59):

0 que é verdade, é verdade. Os homens podem conceber e "acrescentar mentalmente" para si toda a espécie de infernos, toda espécie de duendes, [...] mas a missão da teoria do conhecimento consiste precisamente em demonstrar o carácter irreal, fantástico, reacionário, destes acrescentos mentais.

As reflexões de Lênin, no âmbito da Teoria do Conhecimento a qual não iremos discutir aqui, permitem-nos compreender o poder do idealismo ao construir realidades irreais e permitir a construção de realidades que não existem. Na qual, frequentemente é possível, também, por meio da construção do imaginário da população, principalmente mediante a comunicação social (jornal impresso, televisivo, propagandas e vinhetas comerciais) que constroem consensos e mascaram a luta de classes, a luta dos professores.

Associado a isso, vale destacar que "o uso político de imagens não deve ser reduzido a tentativas de manipulação da opinião pública, [pois elas também oferecem] contribuição para o debate político, desmistificando o poder" (BURKE, 2017, p. 121).

Nessa direção, a partir do método do Materialismo Histórico e Dialético, optou-se por analisar fotografias provenientes de jornais impressos e o conteúdo jornalístico que retratam os movimentos de resistência dos professores no Paraná. Foram coletadas 151 fotografias, no dia 2 de maio de 2017, na Divisão de Documentação Paranaense, da Biblioteca Pública do Paraná, localizada em Curitiba. Dentre as 151 fotografias, foram selecionadas 12 para exposição no corpo deste artigo.

Também foram selecionadas 3 fotografias do livro Massacre 29 de abril: gás, bala, bomba e pimenta contra os professores do Paraná (SCHOENHERR, 2015), oriundas do 


\section{JORNAL DE \\ Políticas Educacionals}

ISSN 1981-1969

Projeto de Extensão Lente Quente do Departamento e Curso de Jornalismo da Universidade Estadual de Ponta Grossa (UEPG).

As 15 fotografias apresentadas representam aspectos que estão presentes nas demais não expostas. Elas foram agrupadas em cinco eixos que emergiram da organização e análise da realidade mediada pelas imagens, sendo:

(1) Greve dos Professores é Desrespeito às Famílias Paranaenses;

(2) Professores Confrontam o Governo e São Baderneiros;

(3) O Poder Bélico do Estado contra os Professores;

(4) A Justiça e o Movimento de Greve;

(5) Falas dos Professores e Fotógrafos.

A análise foi realizada com o método do Materialismo Histórico e Dialético. A discussão ocorreu a partir de categorias do método e de outras que emergiram das fotografias e do conteúdo jornalístico, sendo: a Historicidade, a Ideologia, o Estado, a Hegemonia, a Luta de Classes, os Conflitos e Consensos, as Repressões e as Resistências.

\section{As Lutas dos Professores Paranaenses: conflitos e consensos, repressões e resistências}

Dentre as fotografias coletadas e agrupadas no eixo (1) Greve dos Professores é Desrespeito às Famílias Paranaenses, optou-se por apresentar neste artigo as imagens a seguir (Figs. 2, 3 e 4). De um modo significativo, as reportagens fazem apelo à moralidade conservadora:

Figura 2: Governo espera respostas dos servidores - "Desrespeito às Famílias do Paraná".

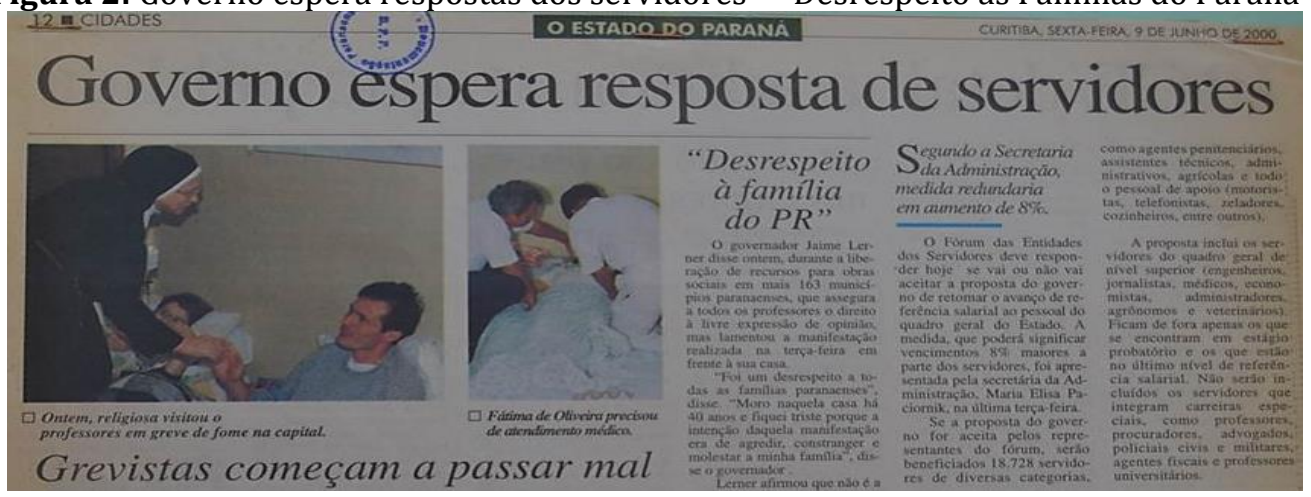

Fonte: $O$ Estado do Paraná, 9 jun. 2000, p. 12. In: Acervo da Divisão de Documentação Paranaense da Biblioteca Pública do Paraná. Fotografia: Rodrigo Diego de Souza, em 2 maio 2017. 


\section{JORNAL DE \\ POLÍTICAS EDUCACIONAIS}

Figura 3: Greve de Professores pode deixar 1,5 milhão sem aulas.

\section{EDUCACÃO II PROFESSORES FAZEM PARALISACAUO Z3/03/0OY ARTO

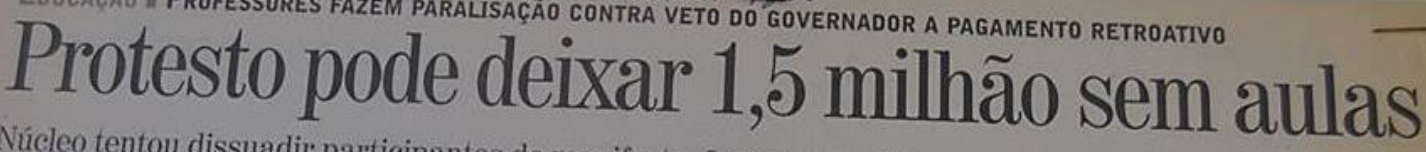

Núcleo tentou dissuadir participantes de manifestação; governo diz que movimento é eleitoreiro

Fonte: Gazeta do Povo, 23 mar. 2004, p. 10. In: Acervo da Divisão de Documentação Paranaense da Biblioteca Pública do Paraná. Fotografia: Rodrigo Diego de Souza, em 2 maio 2017.

Figura 4: Pais temem que filhos percam ano letivo

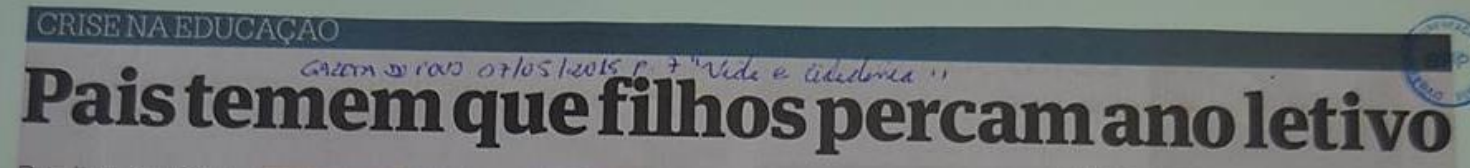

Fonte: Gazeta do Povo, 7 maio 2015, p. 7. In: Acervo da Divisão de Documentação Paranaense da Biblioteca Pública do Paraná. Fotografia: Rodrigo Diego de Souza, em 2 maio 2017.

As reportagens alegam que o movimento de greve dos docentes desrespeita as famílias; que os pais temem que os filhos percam o ano letivo por ocasião da greve; e coloca, em ênfase, um grande número de alunos estava sem aulas. Articulando-se a esse discurso, as fotografias do eixo (2) Professores confrontam o Governo e são Baderneiros, potencializam o apelo à moralidade e ao conservadorismo (Figs. 5, 6, 7 e 8):

Figura 5: Não à Baderna - Ataque do Governo Álvaro Dias aos Professores do Paraná em 1988.

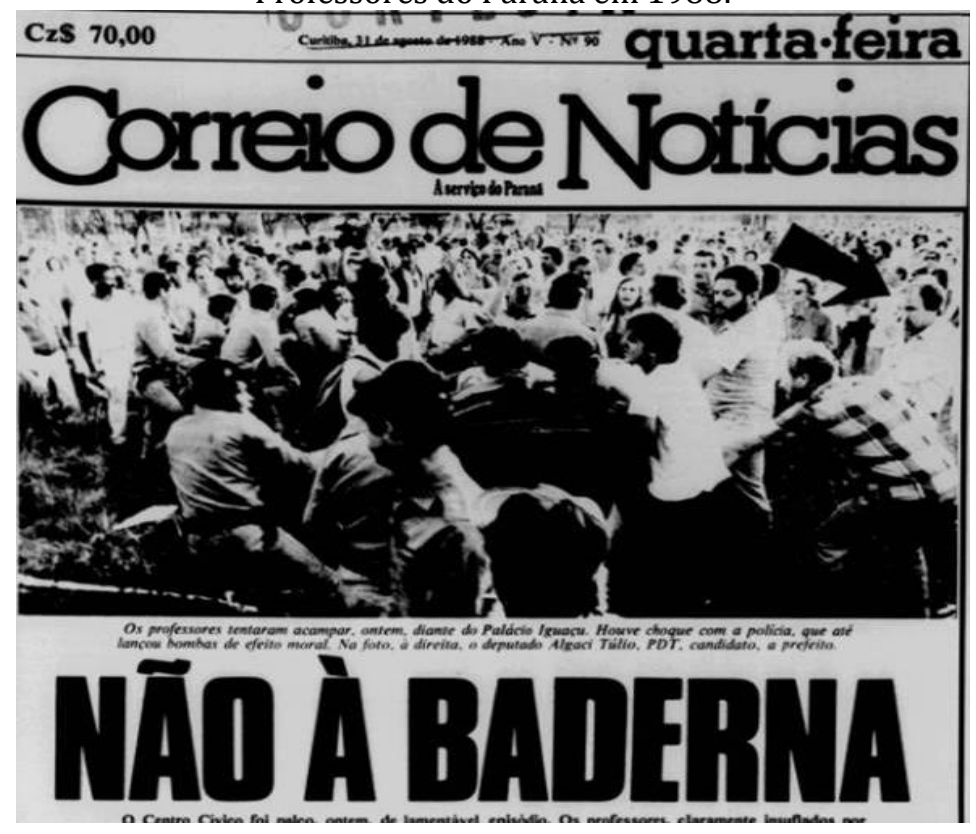




\section{JORNAL DE \\ Políticas EducacionaIs}

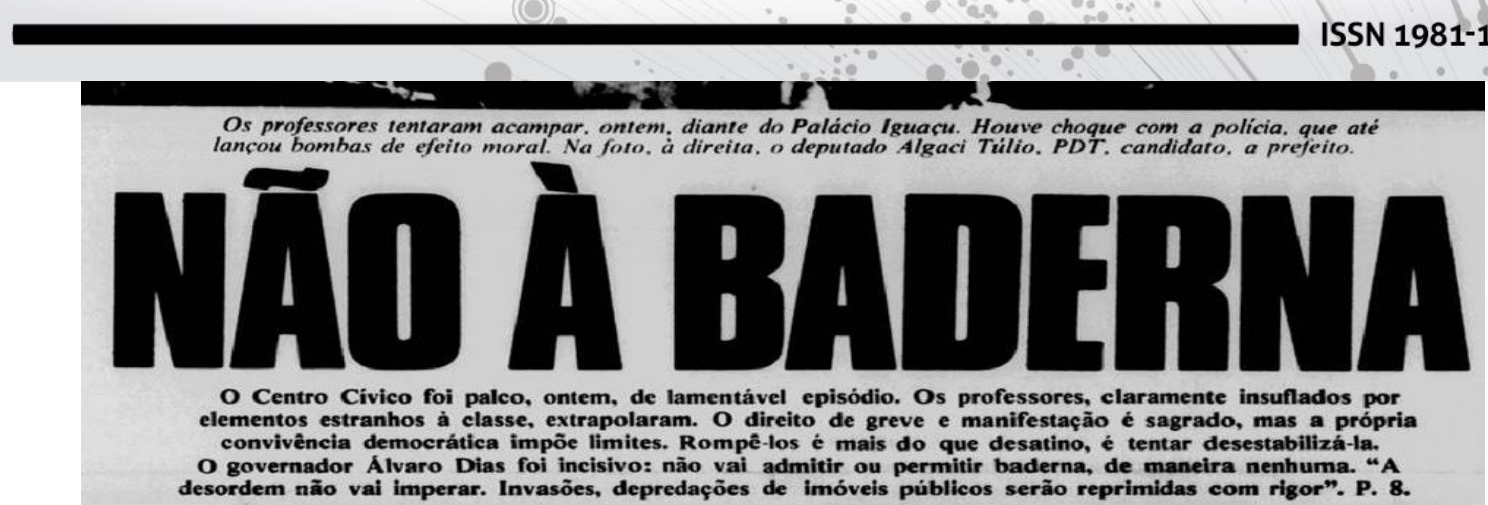

Fonte: Correio de Notícias de 31/08/1988, Capa - versão digitalizada. In: Hemeroteca. Acervo da Divisão de Documentação Paranaense da Biblioteca Pública do Paraná, em 2 maio 2017.

Figura 6: Governo x Professores.

Jornaldo Estado 14.05 .91
Governo x professores
o duro impasse da educação

Fonte: Jornal do Estado, 14 maio 1991. In: Acervo da Divisão de Documentação Paranaense da Biblioteca Pública do Paraná. Fotografia: Rodrigo Diego de Souza, em 2 maio 2017.

Figura 7: Professores iniciam 2014 em guerra.

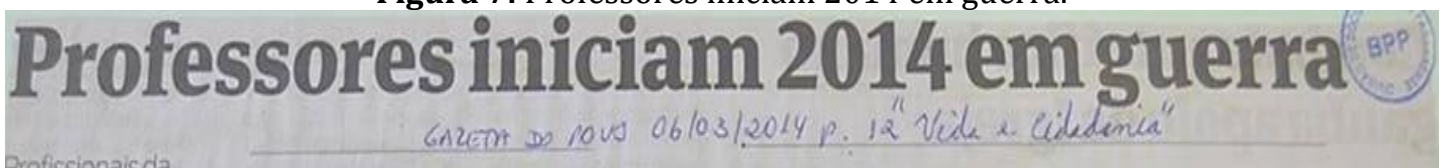

Fonte: Gazeta do Povo, 6 mar. 2014, p. 12. In: Acervo da Divisão de Documentação Paranaense da Biblioteca Pública do Paraná. Fotografia: Rodrigo Diego de Souza, em 2 maio 2017.

Figura 8: Professores voltam a confrontar-se com o

Governo em torno da previdência.

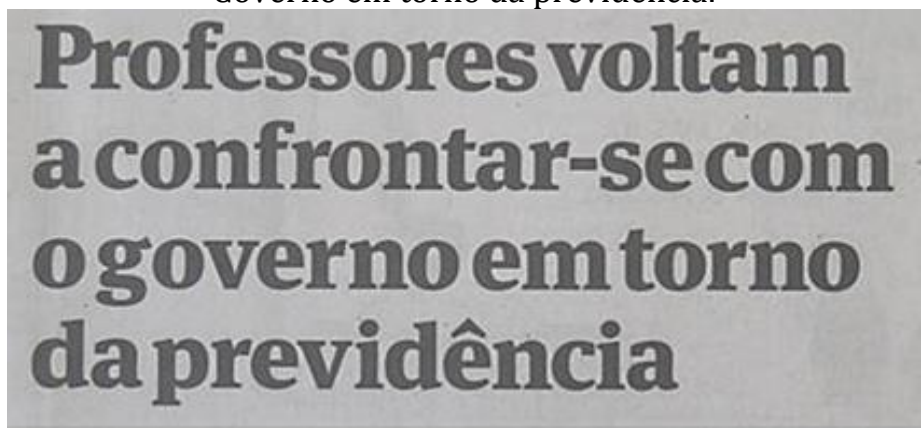

Fonte: Gazeta do Povo, 27 abr. 2015. In: Acervo da Divisão de Documentação Paranaense da Biblioteca Pública do Paraná. Fotografia: Rodrigo Diego de Souza, em 02 maio 2017.

As fotografias denotam a abordagem dos jornais de ampla circulação no Paraná, colocando os Professores como os baderneiros que iniciaram a guerra, não pontuando as ações políticas dos governantes que motivaram as greves. 
SOUZA, R. D. de. As lutas dos professores paranaenses entre os anos de 1988 e 2015 por condições de trabalho: conflitos e consensos, repressões e resistências

\section{JORNAL DE \\ Políticas Educacionals}

Os registros estão relacionados aos diferentes momentos históricos, possuem historicidade, desde o Governo Álvaro Dias (PMDB) de 1988, no qual os professores foram atacados pela Cavalaria da Polícia Militar, ao Governo Roberto Requião (PMDB); Governo Jaime Lerner (PDT) e Governo Carlos Alberto Richa (PSDB). Isso aponta para a realidade de que, historicamente, os professores do Paraná convivem imersos em ataques políticos aos seus direitos trabalhistas e que também desfiguram aquilo que os caracterizam como docentes, ou seja, deixam de ser professores e passam a ser baderneiros, segundo os governantes.

Observam-se as mudanças associadas à forma e ao conteúdo das notícias, que mesmo com o decorrer dos anos, apresentam um discurso mais agressivo e continuam a culpabilizar os professores pela violência policial.

No ano de 1988, o jornal apresenta um texto conservador e afetuoso, capaz de chegar ao coração dos leitores, compadecê-los e construí a realidade na qual os professores são inimigos da população e o governador o responsável pela ordem e a paz, uma história de heróis e vilões: “O governador Álvaro Dias foi incisivo: não vai admitir ou permitir baderna, de maneira nenhuma. 'A desordem não vai imperar. Invasões, depredações de imóveis públicos serão reprimidas com rigor'” (CORREIO DE NOTÍCIAS, 1988, p. 8).

Com o intuito de conter as manifestações, quando o governo não consegue instaurar o consenso, instaura-se a repressão. Entretanto, o governo ao reprimir se utiliza do poder bélico do Estado, por meio do uso de bombas de gás lacrimogênio, spray de pimenta, balas de borracha, entre outros instrumentos, a fim de conter a população.

$\mathrm{Na}$ trajetória histórica das lutas dos professores paranaenses, observa-se o uso do poder bélico contra os professores na luta por seus direitos, de modo mais impactante em duas situações, em 1988, no Governo Álvaro Dias (PMDB) e, em 2015, no Governo Beto Richa (PSDB). Em 1988, os professores são atacados pela Cavalaria da Polícia Militar; e, em 2015, a experiência de desumanização da truculência do Estado autoritário e seu poder de repressão contra os docentes chega a sua máxima expressão durante o 
SOUZA, R. D. de. As lutas dos professores paranaenses entre os anos de 1988 e 2015 por condições de trabalho: conflitos e consensos, repressões e resistências

\section{JORNAL DE Políticas EducacionaIS \\ ISSN 1981-1969}

Massacre $^{10}$ do dia 29 de abril de 2015. Ressalta-se que, atualmente, as ações de repressão do Estado sob o funcionalismo público têm ocorrido em várias regiões do Brasil.

Embora haja um intervalo de 27 anos entre 1988 e 2015, ambos os governos apresentam instrumentos de coação e justificativas semelhantes para a repressão e violência policial. Os dados apresentados nas fotografias apontam que, em 1988, um dos argumentos para o massacre contra os professores era a presença de "elementos estranhos a classe" dos professores que os insuflaram a extrapolar. No ano de 2015, Beto Richa, ao ser questionado sobre o massacre do dia 29 de abril em entrevista ao jornal Gazeta do Povo, afirma a presença de baderneiros e black blocs (REDAÇÃO EPOCA, 2015, s. p.). Em entrevista ao jornal Folha de São Paulo, Beto Richa também aponta como um dos culpados da violência policial, "o pessoal do PT, alguns do PMDB, PSOL e PSTU claro que instigaram. A CUT com presença forte aqui” (REDAÇÃO EPOCA, 2015, não p.).

As Figuras 9, 10, 11 e 12, a seguir, correspondem ao eixo (3) 0 Poder Bélico do Estado contra os Professores, as quais ilustram a força do Estado colocada para contenção dos professores em 1988 e 2015.

Observa-se a culpabilização de Partidos Políticos Brasileiros de centro-esquerda e esquerda e das centrais sindicais. Também o jornal Correio de Notícias, de 31 de agosto de 1988, alega aspectos semelhantes, conforme ilustra a Figura 9 a seguir:

\footnotetext{
${ }^{10}$ Para um esclarecimento sobre o conceito de massacre sugere-se o texto: GADINI, S. L. (Org.). (2015). Coberturas jornalísticas (de)marcadas: a greve dos professores na mídia paranaense em 2015. Ponta Grossa: Estúdio Texto. p. 15.
} 


\section{JORNAL DE \\ Políticas EducacionaIS}

Figura 9: Repressão - Ataque do Governo de Álvaro Dias aos Professores do Paraná em 1988.

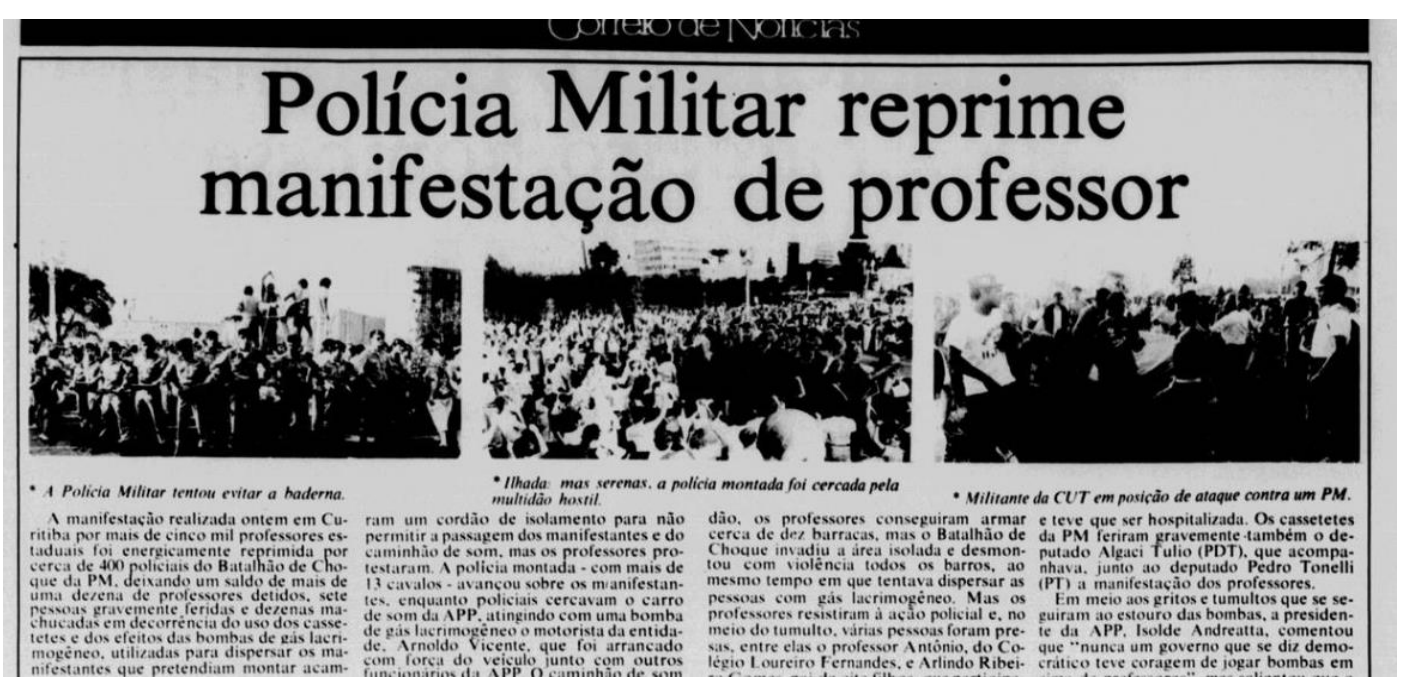

Fonte: Correio de Notícias, 31 ago. 1988, Capa - versão digitalizada. In. Hemeroteca. Acervo da Divisão de Documentação Paranaense da Biblioteca Pública do Paraná, em 02 maio 2017.

As fotografias e a notícia indicam à culpabilização do membro do sindicato como o agente a atacar a Polícia Militar (PM) e, ao mesmo tempo, afirma que a PM está serena e ilhada em meio a uma multidão hostil. Em 2015, Beto Richa também afirma em entrevistas que a culpa do massacre era do movimento black blocs, partidos políticos e da CUT, negando a violência policial do Estado. Mas, as fotografias mostram o contrário.

Figura 10: Manifestação dos Professores, 29 de abril de 2015.

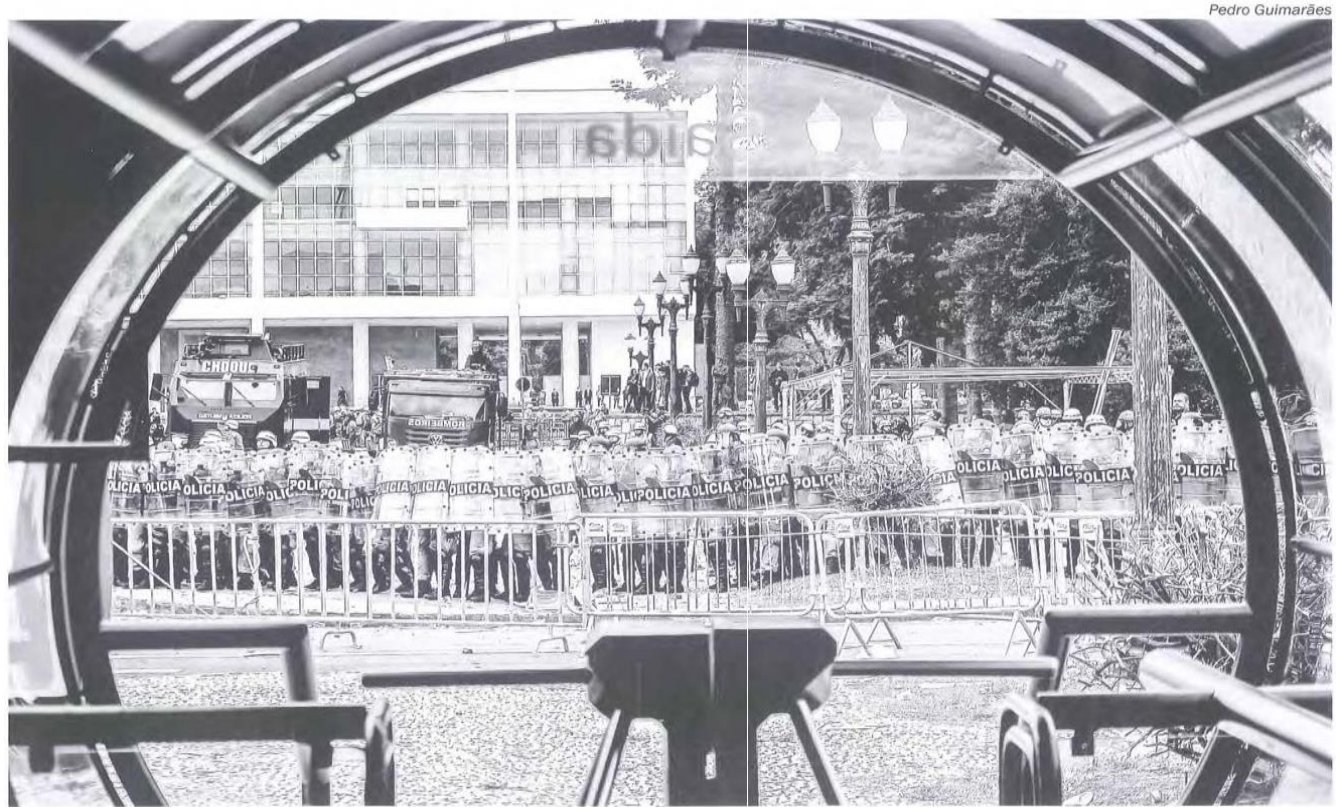

Fonte: Massacre, Projeto Lente Quente (UEPG) (SCHOENHERR, 2015). Fotografia: Pedro Guimarães. 


\section{JORNAL DE \\ Políticas Educacionals}

Figura 11: Manifestação dos Professores, 29 de abril de 2015.

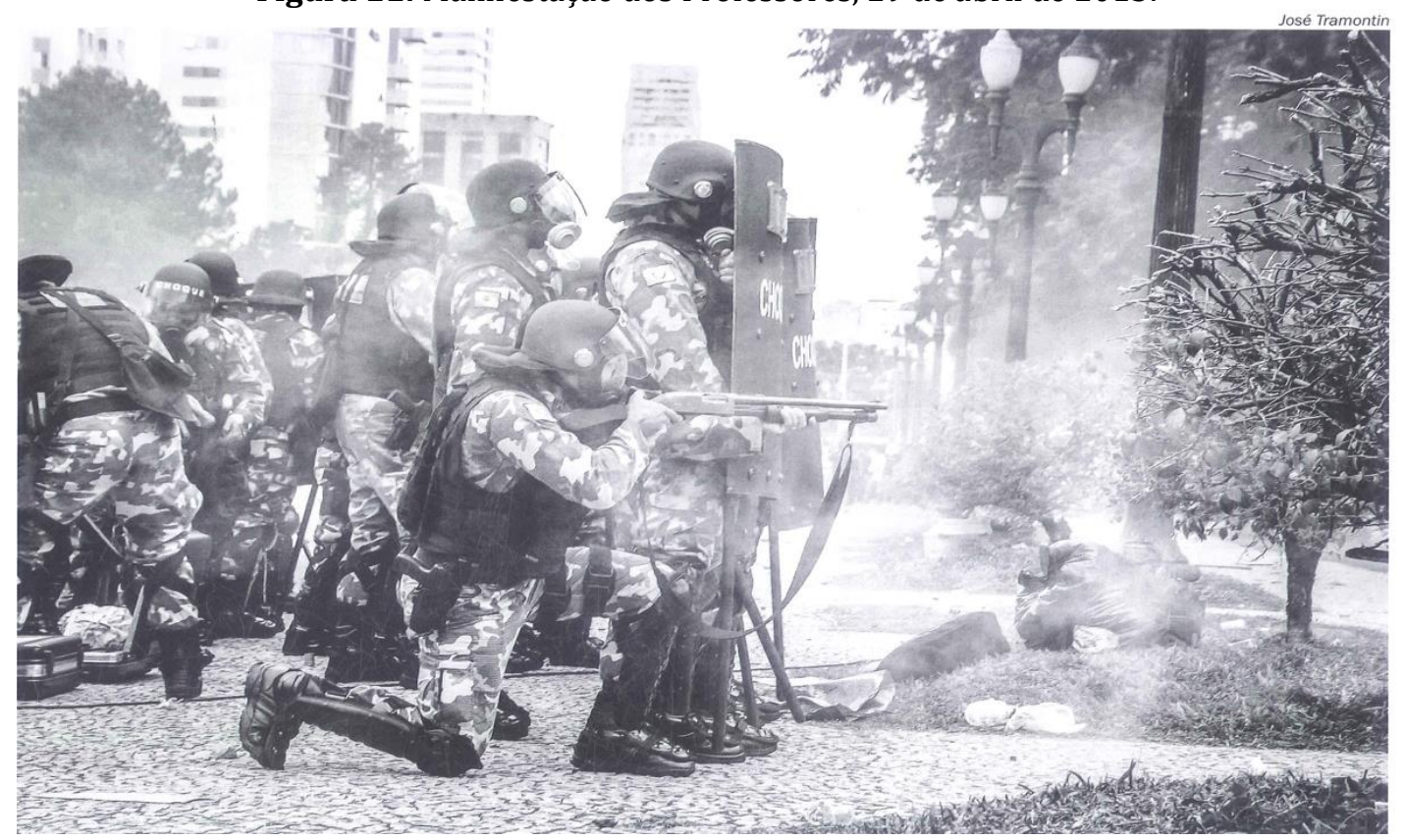

Fonte: Massacre, Projeto Lente Quente (UEPG) (SCHOENHERR, 2015). Fotografia: José Tramontin.

Em destaque, na Figura 12, está uma repórter do jornal televisivo do Paraná em meio às bombas de gás lacrimogênio e spray de pimenta.

Figura 12: Manifestação dos Professores, 29 de abril de 2015.

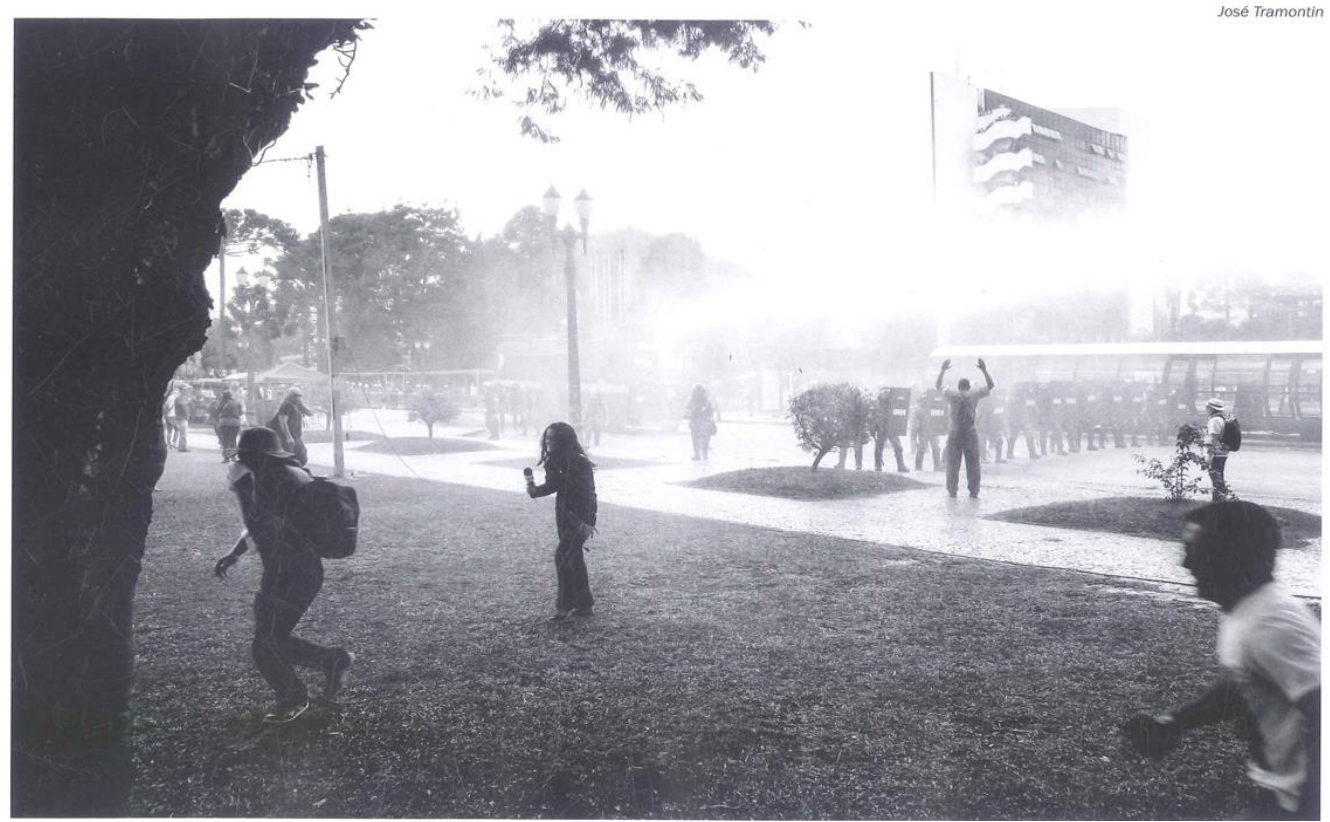

Fonte: Massacre, Projeto Lente Quente (UEPG) (SCHOENHERR, 2015). Fotografia: José Tramontin. 


\section{JORNAL DE POLÍTICAS EDUCACIONAIS

As fotografias retratam o alinhamento das estratégias de repressão utilizadas no Paraná contra os professores, associadas à manipulação da opinião pública quando os governantes apontam que os culpados da "guerra civil" são os "professores baderneiros", mas nunca o próprio Estado e seu poder bélico pronto para reprimir a população na luta por seus direitos, "os militares estão em guerra contra seus compatriotas" (GALEANO, 2019, p. 129).

Apresentou-se até aqui o apelo à moralidade e ao conservadorismo nas representações da realidade dos conflitos, das lutas e resistências dos professores paranaenses, sempre culpabilizando-os e, na ausência do consenso, fazendo uso da repressão.

Observa-se a síntese da relação entre conflitos-lutas-consenso-repressão e resistência. Os interesses antagônicos que permeiam esta relação estão na ótica da luta de classe, da resistência dos professores paranaenses e das ideologias enraizadas historicamente na vida cotidiana dos docentes do Paraná e de toda a classe trabalhadora na sociedade do capital.

Nessa direção, o Estado enquanto legitimação da classe dominante preserva as relações de dominação visto que mantém os trabalhadores em situação de exploração. Caso os proletários, por meio das lutas e resistências, busquem uma transformação da realidade serão identificados como inimigos da sociedade. Karl Marx já sinalizava para isso na obra 018 de Brumário de Luís Bonaparte (MARX, 2011, p. 36-37):

Durante o mês de junho, todas as classes e todos os partidos se uniram no Partido da Ordem contra a classe proletária, considerada o partido da anarquia, do socialismo, do comunismo. Eles 'salvaram' a sociedade dos "inimigos da sociedade". 0 lema repassado por eles às suas tropas consistia nas palavraschave da antiga sociedade: "Propriedade, família, religião, ordem", instigando a cruzada contrarrevolucionária com a frase: 'Sob este signo vencerás'. [...] A sociedade é salva sempre que o círculo dos seus dominadores se estreita, sempre que um interesse mais exclusivo é imposto a um mais amplo. Toda e qualquer reivindicação da mais elementar reforma financeira burguesa, do mais trivial liberalismo, do mais formal republicanismo, da mais banal democracia é simultaneamente punida como "atentado contra a sociedade" e estigmatizada como "socialismo". 
SOUZA, R. D. de. As lutas dos professores paranaenses entre os anos de 1988 e 2015 por condições de trabalho: conflitos e consensos, repressões e resistências

\section{JORNAL DE \\ Políticas EducacionaIS}

Constata-se, assim, nas fotografias analisadas o discurso associado à moralidade, ao conservadorismo, à criminalização das manifestações dos professores atribuindo a eles os adjetivos de baderneiros e, por outro lado, negando a violência policial do Estado, apresentando os PMs (poder bélico) como serenos, tranquilos, consiste no movimento em que a classe dominante apresenta os grevistas como os inimigos da sociedade, os que "deixam os alunos sem aulas", os que "desrespeitam as famílias paranaenses".

Evidencia-se o mascaramento por parte da classe dominante do contraditório, das tensões e conflitos que eclodem com as resistências e lutas docentes frente aos ataques do Estado. Este mascaramento apresenta-se a partir do discurso pacificador da ideologia dominante pautado na prudência, no equilíbrio, na coesão social, no consenso, na defesa da moral, os quais estão ancorados na ideologia conservadora.

Essas características da crítica do discurso ideológico dominante e conservador, que possibilitam o mascaramento do contraditório, compõem os mecanismos de produção e difusão do próprio discurso ideológico da classe dominante, e os modos como este discurso opera na constituição da consciência social da população para construir o consenso, o que é observável também na linguagem utilizada pelos governantes e jornais de maior circulação, que utilizam discursos semelhantes nos anos de 1988 e no ano de 2015: a apresentação de um inimigo comum da sociedade, o estado como protetor e provedor, a não violência policial, e a criminalização do movimento dos professores (MÉSZÁROS, 2008, p. 9).

Com o movimento da ideologia dominante nas raízes da vida cotidiana da população, construindo uma consciência social, e o mascaramento das contradições para o consenso, preservam-se as desigualdades que já estão pressupostas na estrutura das classes e as reproduzem (MÉSZÁROS, 2008, p. 10).

Assim, faz-se necessário compreender que a ideologia não consiste no rótulo da "falsa consciência" sobre a realidade, ou ignorância, ou não apropriação do conhecimento científico; a dimensão da ideologia está alicerçada em “características transhistóricas, que só podem ser entendidas no contexto da reprodução continuada de algumas estruturas vitais do tipo de sociedade de qual emergem" (MÉSZÁROS, 2008, p. 9). Nesse processo, as 


\section{JORNAL DE \\ POLÍTICAS EDUCACIONAIS}

ISSN 1981-1969

lutas entre os professores e o Estado, as resistências, constituem-se em lutas também ideológicas, em lutas por projetos distintos de sociedade e de educação.

Insere-se, nesse contexto, a dimensão Jurídica do Estado, a Justiça frente aos movimentos de greve. As fotografias selecionadas no eixo (4) A Justiça e o Movimento de Greve expressam a intersecção entre a Justiça e o Movimento dos Professores, conforme segue (Figs. 13 e 14):

Figura 13: Justiça decide pelo fim da greve.

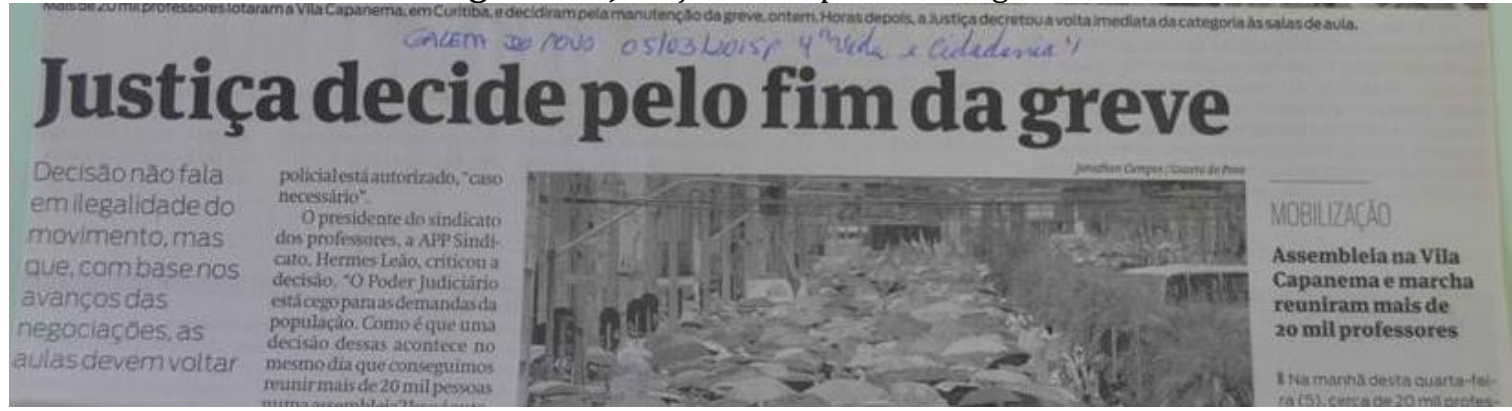

Fonte: Gazeta do Povo, 5 mar. 2015. In. Acervo da Divisão de Documentação Paranaense da Biblioteca Pública do Paraná. Fotografia: Rodrigo Diego de Souza, em 2 maio 2017.

Figura 14: Justiça considera greve irregular.

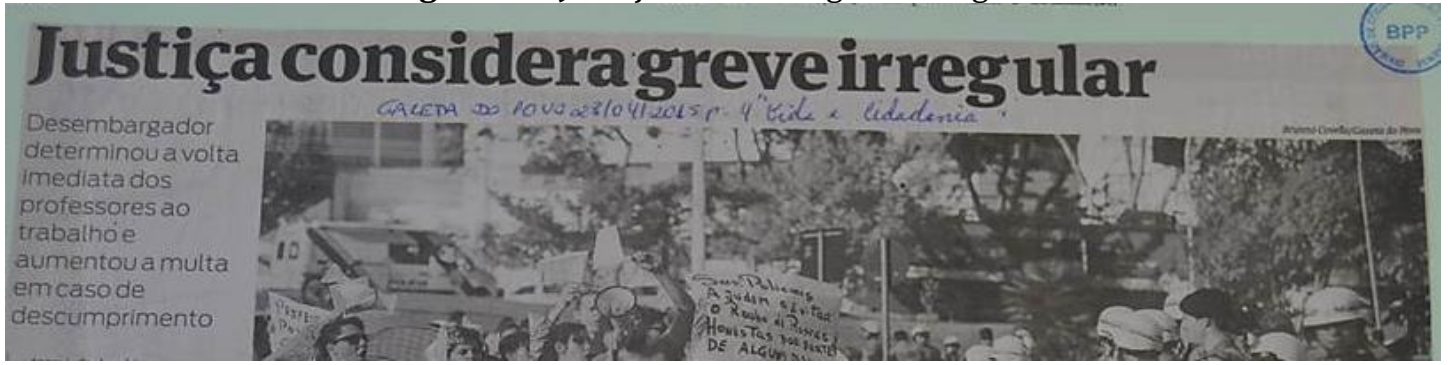

Fonte: Gazeta do Povo, 27 abr. 2015. In. Acervo da Divisão de Documentação Paranaense da Biblioteca Pública do Paraná. Fotografia: Rodrigo Diego de Souza, em 2 maio 2017.

Considerando o alinhamento institucional da máquina governamental - neste caso, a dimensão jurídica alinhada ao Governo de Estado -, observa-se que independentemente das demandas trazidas pelos professores e dos movimentos de greve terem sido deliberados em Assembleias, a justiça entra em cena de modo impositivo com o intuito de encerrar a greve e contribuir para a manutenção da ordem, em conjunto com o Estado. 


\section{JORNAL DE Políticas Educacionals

Vinculados aos movimentos de luta e resistência dos docentes, a busca do consenso por parte do governo e da repressão dos movimentos com o poder bélico do Estado, o governo utiliza mais uma "ferramenta" do poder estatal: a esfera jurídica.

Rancière (2014, p. 82) aponta que os especialistas do Estado têm uma função fundamental na legitimação do Estado a partir de uma ideologia única - a da classe dominante -, atrelada às tomadas de decisão a partir de uma neutralidade da instituição estatal, ou seja, uma neutralidade ideológica.

Esta pseudoneutralidade ideológica é difundida também por meio de termos e noções como igualdade, direito, justiça. As contradições em questão não estão direcionadas aos termos em si, mas ao conteúdo ideológico conservador da classe dominante burguesa que é difundido por meio desses termos, conforme Harvey (2005, p. 82) também ilustra:

[...] se [as] essas ideias dominantes têm de ganhar aceitação como representantes do "interesse comum", precisam ser apresentadas como idealizações abstratas, como verdades eternamente universais. Assim, essas ideias devem ser apresentadas como se tivessem uma existência autônoma. As noções de "justiça", "direito", "liberdade" são apresentadas como se tivessem um significado independente de qualquer interesse de classe específico. [...] Além disso, se o Estado pode ser representado como idealização abstrata do interesse comum, o próprio Estado pode se tornar encarnação abstrata do princípio "moral" (nacionalismo, patriotismo, fascismo, todos [os Estados] apelam para isso em algum grau).

Nessa direção, não há neutralidade ideológica, e segundo Engels (2010, p. 213), o Estado emerge como aquele capaz de produzir os consensos necessários, o equilíbrio, a relação entre as classes de modo pacificado a fim de dar continuidade à reprodução da sociabilidade capitalista.

No contexto das lutas docentes, o Estado, enquanto institucionalização da classe burguesa, associado ao poder bélico, à manipulação da opinião pública e a esfera jurídica, apresenta-se como um todo organizado para a manutenção da hegemonia e do consenso, como Marx e Engels apontam no Manifesto Comunista (2005, p. 42): “A burguesia 


\section{JORNAL DE \\ Políticas EducacionaIS}

ISSN 1981-1969

despojou de sua auréola todas as atividades até então reputadas como dignas e encaradas com o piedoso respeito. Fez do médico, do jurista, do sacerdote, do poeta, do sábio seus servidores assalariados".

Em contraposição aos elementos apresentados, os jornais também apresentam as falas dos professores (Fig. 15) que vivenciaram os ataques do Estado no dia 29 de abril de 2015, alocadas no eixo (5) Falas dos Professores e Fotógrafos.

Figura 15: Falas e depoimentos dos professores acerca do dia 29 de abril de 2015.
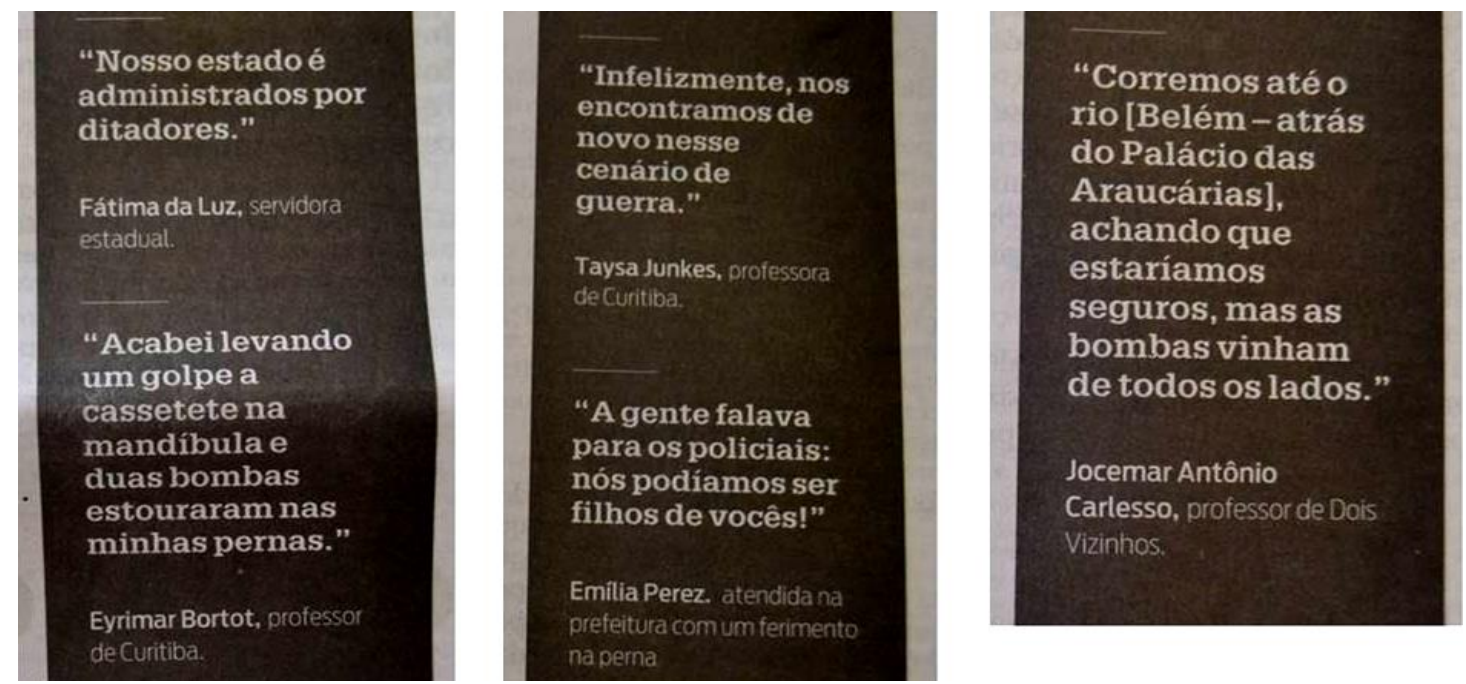

Fonte: Gazeta do Povo, 30 abr. 2015. In. Acervo da Divisão de Documentação Paranaense da Biblioteca Pública do Paraná. Fotografia: Rodrigo Diego de Souza, em 2 maio 2017.

Associadas às falas dos professores, têm-se depoimentos dos fotógrafos do Projeto Lente Quente - UEPG (SCHOENHERR, 2015):

[André Lopes] Quando vi um professor atingido cair na minha frente, me senti dividido e provocado. Questionei-me em uma fração de segundo: de que forma eu ajudaria mais? Optei por registrar, e fiz isso até o último minuto em que havia armas apontadas na nossa direção. (apud SCHOENHERR, 2015, p. 116).

[Rodrigo Menegat] A sensação de impotência foi imensa. Pessoas corriam asfixiadas e ensanguentadas e eu não podia fazer nada além de fotografar, atordoado por tamanha brutalidade. Registrar o que acontecia era mais do que um trabalho. Era uma obrigação. (apud SCHOENHERR, 2015, p. 117). 
SOUZA, R. D. de. As lutas dos professores paranaenses entre os anos de 1988 e 2015 por condições de trabalho: conflitos e consensos, repressões e resistências

\section{JORNAL DE \\ Políticas Educacionals \\ ISSN 1981-1969}

As falas e depoimentos apontam para informações que também se apresentam nas fotografias e manchetes de jornais, mas, por outro lado, o mascaramento desta realidade de violência e sofrimento, no discurso ideológico dominante do Estado para forçar o consenso e a pacificação, eximindo-se de apontar que as causas da violência policial e os motivos das manifestações não são responsabilidade do Estado, mas culpa dos docentes.

Nessa constatação está um dos modos de operação da ideologia, a qual ocorre por meio da inversão das coisas e fatos da realidade, "se, em toda ideologia, os homens e suas relações aparecem de cabeça para baixo como numa câmara escura, esse fenômeno resulta do seu processo histórico de vida". Essa inversão do real se dá nas ações políticas que se apresentam ideologicamente (MARX, ENGELS; 2007, p. 94).

O governo promove uma inversão do real, pois não contrata professores aprovados em concurso público e em processos seletivos, não cumpre com as Políticas de Valorização e carreira como a Lei do PSPN e a Lei da Data-Base para a reposição inflacionária, agride fisicamente e psicologicamente os professores, diminui as horas atividade dos docentes, cada vez mais precarizando e intensificando o trabalho docente. Além dos casos de corrupção e desvio de verbas para a infraestrutura das escolas, como a Operação Quadro Negro ${ }^{11 .}$

\section{Considerações finais}

Este artigo contextualizou histórica e politicamente as lutas dos professores do Paraná por condições de trabalho e discutiu as contradições que permeiam as lutas e a desvalorização do trabalho docente.

Constatou-se que, dentre as contribuições desta pesquisa, há:

(1) a denúncia das condições de trabalho e lutas docentes, frente a construção do consenso operado pelo estado e pela mídia nos anos de 1988 a 2015;

(2) avanços para as pesquisas em Trabalho e Educação no contexto do Paraná, com os dados históricos e políticos mediados pelas fotografias, que permitiram apontar as

\footnotetext{
${ }^{11}$ https://www.gazetadopovo.com.br/tudo-sobre/operacao-quadro-negro/6/ Acesso em 19 mai. 2021.
} 


\section{JORNAL DE Políticas Educacionals

ações políticas construídas histórica e ideologicamente de culpabilização docente mascarando a irresponsabilidade do Estado;

(3) a contribuição para a análise das lutas docentes em outras regiões brasileiras, pois a desvalorização docente no Brasil é um fenômeno nacional e não apenas localizado.

A pesquisa descrita neste artigo não esgota as discussões e reflexões acerca das condições de trabalho dos professores e, ao mesmo tempo em que apresenta as lutas dos docentes do Paraná, representa as condições e diferentes lutas docentes travadas em outros estados e municípios brasileiros. Ressaltando-se, assim, a importância da formulação e implementação de políticas de valorização do magistério que proporcionem condições dignas de trabalho, salário digno e manutenção na profissão e carreira.

\section{Referências}

BRASIL. Lei no 11.738, de 2008. Instituiu o Piso Salarial Profissional Nacional para os Profissionais do Magistério Público da Educação Básica. 2008. Disponível em: http://www.planalto.gov.br/ccivil 03/ ato2007-2010/2008/lei/l11738.htm. Acesso em: 19 ago. 2017.

BURKE, P. Testemunha ocular: o uso de imagens como evidência histórica. Trad. por Vera Maria Xavier dos Santos. São Paulo: Ed. Unesp. 2017.

CORREIO DE NOTÍCIAS. Não à Baderna. Jornal Correio de Notícias, Ano V, n. 90, 31 ago. 1988. In. Hemeroteca - Acervo da Divisão de Documentação Paranaense da Biblioteca Pública do Paraná. 1988.

CENTRAL ÚNICA DOS TRABALHADORES. Encontro nacional de mulheres da cut: Trabalhadoras em luta por Igualdade, Liberdade e Autonomia, 8., 2015, Brasília. Caderno de Resoluções. Comissão organizadora do 8 encontro Nacional de Mulheres da CUT. São Paulo: Central Única dos Trabalhadores. 2015. Disponível em: https://cut.org.br/system/uploads/action file version/160fcc5948869a2979c318cadb 8b6db6/file/web-caderno-de-resolucoes-8-encontro-nacional-das-mulheres-da-cut.pdf. Acesso em: 9 jan. 2019.

ENGELS, F. A origem da família, da propriedade privada e do Estado. 2. ed. SP: Expressão popular. 2010.

GALEANO, E. 0 livro dos abraços. 1a. ed. [2005]. Reimpressão [2019]. Porto Alegre: L\&PM. (Coleção L\&PM POCKET).

GROCHOSKA, M. A. Políticas educacionais e a valorização do professor: carreira e qualidade de vida dos professores de educação básica do município de São José 


\section{JORNAL DE POLÍTICAS EDUCACIONAIS

dos Pinhais/PR. Tese (Doutorado em Educação) - Programa de pós-Graduação em Educação, Universidade Federal do Paraná, Curitiba. 2015.

HARVEY, D. A produção capitalista do espaço. São Paulo: Annablume. 2005.

IPARDES. Indicadores Selecionados - Paraná/Instituto Paranaense de Desenvolvimento Econômico e Social. - Curitiba : IPARDES, 2017. Disponível em: http://www.ipardes.pr.gov.br/pdf/indices/indicadores selecionados.pdf. Acesso em: 15 ago. 2017.

IBGE. Divisão Regional do Brasil em Mesorregiões e Microrregiões Geográficas. v.1, 1990. Disponível em:

https://biblioteca.ibge.gov.br/visualizacao/monografias/GEBIS\%20\%20RJ/DRB/Divisao\%20regional v01.pdf. Acesso em: 15 ago. 2017.

IPARDES; BRDE. Leituras regionais: Mesorregião Geográfica Sudeste Paranaense/Instituto Paranaense de Desenvolvimento Econômico e Social. - Curitiba : IPARDES : BRDE, 2004. Acesso em: 15 ago. 2017. Disponível em: http://www.ipardes.gov.br/biblioteca/docs/leituras reg meso sudeste.pdf

LÊNIN, V. I. Materialismo e Empiriocriticismo: notas críticas sobre uma filosofia reacionária. Lisboa, Moscovo: Edições Avante - Edições Progresso. 1982.

MARX, K. 018 de brumário de Luís Bonaparte. Trad. e notas Nélio Schneider, prólogo Herbert Marcuse. São Paulo: Boitempo. 2011.

MARX, K. \& ENGELS, F. A ideologia alemã: crítica da mais recente filosofia alemã em seus representantes Feuerbach, B. Bauer e Stimer, e do socialismo alemão em seus diferentes profetas (1845-1846). São Paulo: Boitempo. 2007.

MARX, K. \& ENGELS, F. Manifesto Comunista. São Paulo: Boitempo, 2005.

MASSON, G. A valorização dos professores e a educação básica nos estados. Revista Retratos da Escola, Brasília, v. 10, n. 18, p. 157-174, jan./jun. 2016. Disponível em: http://retratosdaescola.emnuvens.com.br/rde/article/viewFile/656/693. Acesso em: 28 jun. 2019.

MÉSZÁROS, I. Filosofia, ideologia e ciência social. São Paulo: Boitempo, 2008.

MORETTI, J. S. S. \& MASSON, G. A valorização dos professores em municípios do Paraná: análise dos planos de carreira. Jornal de Políticas Educacionais, v. 9, n. 17 e 18, p. 111 124, jan.-jun. e ago.-dez. 2015. Disponível em:

https://revistas.ufpr.br/jpe/article/view/44106. Acesso em: 28 jun. 2019.

RANCIÈRE, J. 0 ódio à democracia. São Paulo: Boitempo, 2014.

REDAÇÃO ÉPOCA. Beto Richa culpa “black blocs” pela violência na manifestação de professores: segundo o governador do Paraná, os relatos do protesto de quarta indicam que "não houve violência" policial. Revista época [on-line], Filtro, não paginado, 30 abr. 2015. Disponível em: https://epoca.globo.com/tempo/filtro/noticia/2015/04/beto- 
SOUZA, R. D. de. As lutas dos professores paranaenses entre os anos de 1988 e 2015 por condições de trabalho: conflitos e consensos, repressões e resistências

\section{JORNAL DE \\ Políticas Educacionals \\ ISSN 1981-1969}

richa-culpa-black-blocs-pela-violencia-na-manifestacao-de-professores.html. Acesso em: 22 jan. 2019.

SCHOENHERR, R. (Org.). Massacre 29 de abril: gás, bala, bomba e pimenta contra os professores do Paraná. Rafael Schoenherr (Org.). Ponta Grossa: Estúdio Texto, 2015.

STECA, L. C. \& FLORES, M. D. História do Paraná do século XVI à década de 1950. Londrina: Ed. UEL, 2008. 


\title{
JORNAL DE \\ Políticas Educacionals

JORNAL DE

Políticas Educacionals

ISSN 1981-1969

Volume 15

e80487

10 de setembro de 2021

(c)

SORE RIGHIS RESERED

O Copyright é retido pelo/a autor/a (ou primeiro co-autor) que outorga o direito da primeira publicação ao Jornal de Políticas Educacionais. Mais informação da licença de Creative Commons encontram-se em http://creativecommons.org/licenses/by-nc-nd/4.0. Qualquer outro uso deve ser aprovado em conjunto pelo/s autor/es e pelo periódico.

JORNAL DE PolíticAS EDUCACIONAIS é uma publicação do Núcleo de Políticas Educacionais do Setor de Educação da Universidade Federal do Paraná - NuPE/UFPR, em consórcio com a Linha de Pesquisa em Políticas Educacionais do Programa de Pós-Graduação em Educação - PPGE/UFPR, que aceita colaboração, reservando-se o direito de publicar ou não o material espontaneamente enviado à redação. As colaborações devem ser enviadas ao NuPE/UFPR, conforme orientações contidas nas páginas do periódico na internet: http://revistas.ufpr.br/jpe.

\section{INDEXAÇÃO:}

BASE DE DADOS
Sumário.Org
Google Scholar
BASE
Dimensions
DIRETÓRIOS
Erih Plus
Latindex
Diadorim
EZB
ROAD
Journal 4-free

\author{
INDICES \\ Index Copernicus \\ Cite Factor \\ PORTAIS \\ LiVre \\ Capes \\ Science Open \\ World Wide Science
}

(Periódico integralmente disponível apenas em via eletrônica)

Jornal de Políticas Educacionais / Núcleo de Políticas Educacionais da Universidade Federal do Paraná NuPE/UFPR - v.1, n. 1 (1ํㅗ semestre de 2007) - Curitiba: NuPE/UFPR.

Volume 15, e80487 - Setembro de 2021

ISSN 1981-1969

1. Educação - Periódicos. 2. Política Educacional - Periódicos. I. NuPE/UFPR 
Comitê Editorial:

Elisângela Scaff (UFPR)

Daniela de Oliveira Pires (UFPR)

Conselho Editorial:

Andréa Barbosa Gouveia (UFPR - Brasil), Angela Maria Martins (FCC, Brasil), Antonia Almeida Silva (UEFS, Brasil), Cesar Tello (Universidad Nacional Tres Febrero, Argentina), Cristiane Machado (Unicamp- Brasil), Elton Luiz Nardi (UNOESC, Brasil), Fernanda Saforcada (Universidad de Buenos Aires - UBA - Argentina), Gladys Beatriz Barreyro (USP - Brasil), Gilda Cardoso Araújo (UFES - Brasil), Gustavo Enrique Fischman (Arizona State University - USA), Janete Maria Lins de Azevedo (UFPE, Brasil), Jefferson Mainardes (UEPG Brasil), João Ferreira de Oliveira (UFG - Brasil), Jorge Manuel Gorostiaga (UNSAM - Argentina),Juca Gil (UFRGS - Brasil), Luciana Rosa Marques (UFPE, Brasil), Luiz Souza Júnior (UFPB - Brasil), Marcia Aparecida Jacomini (Unifesp-Brasil), Maria Dilnéia Espíndola Fernandes (UFMS, Brasil), Ney Cristina Monteiro de Oliveira (UFPA - Brasil), Nicolás Bentancur, (Universidad de la República de Uruguay), Nora Krawczyk (Unicamp- Brasil) Rodrigo da Silva Pereira (UFBA, Brasil), Robert Verhine (UFBA - Brasil), Rosana Cruz (UFPI - Brasil), Rubens Barbosa Camargo (USP - Brasil), Sebastián Donoso Díaz (Universidad de Talca Chile), Theresa Adrião (UNICAMP - Brasil), Vera Maria Vidal Peroni (UFRGS - Brasil).

Créditos e Agradecimentos:

Revisão de Língua Portuguesa, Abstract e Resumen: Programa de apoio às publicações científicas periódicas da UFPR

Arte e diagramação: Tiago Tavares (tiagotav@gmail.com)

Jornal de Políticas Educacionais

Universidade Federal do Paraná

Setor de Educação

Núcleo de Políticas Educacionais - NuPE/UFPR

Avenida Sete de Setembro, 2645

2 o andar, Sala 213

80.230-010 - Curitiba - PR - Brasil

Tel.: 41-3535-6264

jpe@ufpr.br

http://revistas.ufpr.br/jpe 